\title{
Strengthening Motivation in the Mathematical Engineering Teaching Processes - A Proposal from Gamification and Game-Based Learning
}

\author{
https://doi.org/10.3991/ijet.v16i06.16163 \\ Sergio Zabala-Vargas ${ }^{\left({ }^{凶}\right)}$, Lewis García-Mora, \\ Edgar Arciniegas-Hernández, Jerson Reina-Medrano \\ Universidad Santo Tomás, Bucaramanga Colombia \\ sergio.zabalalustabuca.edu.co \\ Bárbara de Benito-Crosetti, Antonia Darder-Mésquida \\ Universitat Illes Balears, Palma, España
}

\begin{abstract}
Gamification and game-based learning (GBL) has been widely implemented in educational processes, mainly in elementary education; it has been applied less frequently in university education. The objective was to test the effect of game-mediated teaching strategies on mathematics teaching in first-year engineering students. A quantitative study was done within the framework of a design-based research. Eighty-one (81) students participated in the research, all from the Differential Calculus course. Twelve (12) didactic units were designed. The instrument used was the Synthesized Instructional Materials Motivation Survey (SIMMS), adapted to record the categories of Attention, Relevance, Confidence and Satisfaction (Keller's motivational model). A significant contribution of the pedagogical strategy and the different categories of motivation was verified, whereas the significance between collaboration and motivation was also evident (intervention 2). Finally, the strategy can provide preliminary evidences in reducing dropout. In conclusion, game-based learning can be used to strengthen educational processes in engineering.
\end{abstract}

Keywords - Collaboration, Game-based learning, gamification, learning strategies, motivation

\section{Introduction}

Gamification is a concept that has been widely developed in recent years. In simple terms, it is the use of game design elements in non-game context [1]. Gamification is used in different environments, such as health promotion, increased productivity, organizational development, educational field and becoming loyal to a brand, among others [2]. In the educational field, gamification has created great interest among academicians and researchers.

The exploration of various pedagogical elements that use gamification in instructional design has been promoted. This has provided students with engaging experi- 
ences and improved quality of academic programs [3]. According to [4] there are multiple challenges regarding the incorporation of gamification. These challenges include: Gamification needs a systematic approach to achieve the desired positive results, and instructors and teachers do not have enough resources and knowledge to plan and develop successful gamification strategies in their classes.

On the other hand, Game-Based Learning (GBL) describes an environment where the content of the game and the game itself improve the acquisition of skills, competencies and knowledge [5]. Game activities involve problem-solving scenarios and challenges that give learners the feeling of success and achievement [6]. A key aspect of the GBL is that the use of games is always oriented towards education [7]. Also, the term GBL describes how gamified content is used as an e-learning technique to achieve learning objectives. Thus, instructional designers who want to incorporate games must carefully align elements such as game mechanics and dynamics. The elements of the game are: Goals and objectives, narrative, rules, freedom to choose, freedom to make mistakes, rewards, feedback, visible status, cooperation and competition, time restriction, progress and surprise [8]. There must be a compelling narrative and a feedback system to generate the student's feeling of continuous progression. This allows you to capture the player's attention and keep him or her immersed in the educational experience [3], [9].

In this sense, the use of games in educational processes is widely documented in literature reviews [3], [10]-[14]. Positive and negative aspects are highlighted when implementing gamification strategies. [15] presents an experimental study where the motivation of students in an academic process is strengthened with the use of educational games. Gameplay and narrative are key factors in incorporating games with young people [16]. The engagement in the educational process is enhanced with the use of games [17]. Also, a lot of research shows that academic performance and motivation increase with the implementation of game-based learning [18]-[25]. In contrast, [26] presents in its results that the students in the gamified course show less motivation, satisfaction and empowerment than those related to the non-gamified class. Similarly, another research indicates that game elements can increase quantitative performance but not the motivation of students in the educational process [27].

The purpose of this document is to present a study that examines new pedagogical strategies for mathematics courses in engineering programs. The importance of mathematics in such programs is clearly established in the academic literature [28][30].However, at the beginning of this research in the engineering programs of the Universidad Santo Tomás (Bucaramanga-Colombia), there was a $40 \%$ desertion/ dropout of the entire program [31]. This dropout is generated by many factors [32][34]. Particularly for this case study, there is evidence of dropout associated with two factors: low levels of motivation of students towards the appropriation of mathematical concepts, and low levels of academic performance mainly in first year mathematics courses.

The literature review in SCOPUS shows an increasing trend of research in the area and interest from the academic community. In the last 10 years, 1260 documents have been published with an increasing trend (55 in 2010, 130 in 2015 and 2010 in 2019). By further specifying the review with the criterion of Higher Education, the number is 
reduced to 158 documents. This allows us to observe an area with gaps in knowledge where contributions are important. Associated with the above, the literature review presented in [13] relates experiences of applying Game Based Learning and Gamification in the teaching of mathematics in higher education. The use of educational digital games and the promotion of variables such as motivation and favorable behavior development are observed.

Regarding motivation, this concept refers to what people want, what they choose to do and what they commit to doing. It is defined as what explains the orientation and size of a person's behavior [35]. For the present investigation, the ARCS model of J. Keller, which is one of the most widely mentioned theories of motivation in education, has been suggested to become the standard by which a game increases learning motivation [19]. The ARCS model has been used for instructional designs of motivation-based programs [36]-[38]. Keller's model has also been used in computer-based learning [39]-[42] . Finally, there is also evidence of the use of the ARCS model in gamification and GBL [43]-[48]. In the ARCS model, motivation is divided into four major categories:

1) Attention: Aimed at capturing students' interest. It proposes to stimulate curiosity to learn

2) Relevance: Focused on connecting personal needs and objectives with the learning process

3) Confidence: Oriented to help students feel that they will succeed in their academic process and be able to control this success

4) Satisfaction: Focused on reinforcing the student's interest in continuing to learn, through rewards (internal and external) [35].

Another relevant concept for research is collaboration and its contribution to student motivation. Collaborative work and its relationship with the implementation of pedagogical strategies with GBL is widely documented in the literature [18], [49][52]. This concept is associated with collaborative learning, which is one of the focuses of interest for the case study institution. Up to this point, there is evidence that it is possible to improve students' motivation and academic performance by using innovative pedagogical strategies such as game-based learning (GBL) and gamification. The methodology associated with the study is listed below.

\section{Methodology}

The design-based research (DBR) methodology was selected. DBR is a systematic but flexible methodology aimed at improving educational practice through analysis, design, development and iterative implementation. DBR is based on the development of solutions to problems, called interventions [53], [54]. The selected paradigm is mixed. For the present document, only the quantitative aspect is presented. The main output variable is student motivation. A secondary variable is dropout. 


\subsection{Participants}

The research participants are related in three interventions or iterations. The study participants were 106 first-year engineering students (intervention $0=25$, intervention $1=26$ and intervention $2=55$ ). The age of the population is between 17 and 22 . All students belong to the Differential Calculus course. The participants were preassigned by the Department of Basic Sciences. The assignment of the groups was not random. No control group was used in the design. Intervention 0 made it possible to calibrate the instruments and the preliminary work dynamics [14].

\subsection{Research questions}

The purpose of this research study was to identify the effect of gamification and game-based learning on the motivation and dropout levels of first-year engineering mathematics students. The research questions were:

1. Is there a relationship between the use of a Gamification / GBL-based pedagogical strategy and student motivation?

2. Is there a relationship between collaboration in the Gamification / GBL-based pedagogical strategy and student motivation?

3. Is there a relationship between the use of a Gamification / GBL-based pedagogical strategy and the dropout levels?

\subsection{Procedure}

The research began with the design of the pedagogical strategy and the didactic units that comprise it. The team of teachers of the differential calculus courses was trained on the technological tools and the concepts of GBL and gamification. The designed teaching units were applied to the target population. The IMMS instrument (particularly the SIMMS adaptation presented in the next section) and a collaboration survey at the end of the intervention were used.

Data analysis for research question 1 was performed from the review of the most frequent answer (mode) for each question. In each intervention, the different categories of the ARCS model were compared using a weighted average for each question. The weights used were: 50\% (Level 5- IMMS), 40\% (Level 4- IMMS) and 10\% (Level 3- IMMS). For research question 2, a Pearson correlation analysis was performed between the variables: Collaboration-Attention, Collaboration-Relevance, Collaboration-Confidence and Collaboration-Satisfaction. The two-tailed test was used to validate the significance of the data.

\subsection{Instruments and materials}

Two types of instruments were used in the investigation: IMMS and Collaboration Survey. The IMMS (Instructional Materials Motivation Survey) instrument has been widely used in the academic literature to determine the motivation levels of a popula- 
tion associated with a curriculum design or intervention [19], [55]-[58]. The original proposal has 36 questions distributed as follows: Attention (12), Relevance (9), Confidence (9) and Satisfaction (6). The validity of the instrument is presented in [35]. For this research, following the experience of [59] a synthesized version of the IMMS, the Synthesized Instructional Materials Motivation Survey (SIMMS) was implemented. SIMMS has seventeen items with the following distribution: Attention (5), Relevance (4), Satisfaction (4) and Confidence (4). The questions / items are presented in Table 1. A Likert scale was used. Level $1=$ Not true, Level $2=$ Slightly true, Level 3 = Moderately true, Level $4=$ Mostly true and Level $5=$ Very true. On the other hand, the Collaboration Survey had 4 questions about the importance and relevance of collaboration in the development of the pedagogical strategy. The same SIMMS Likert scale was used. This survey is presented in Table 1.

Table 1. Collaboration Survey

\begin{tabular}{|c|c|c|c|c|c|}
\hline \multirow{2}{*}{ Collaboration Item } & \multicolumn{5}{|c|}{$\%$} \\
\hline & 1 & 2 & 3 & 4 & 5 \\
\hline The positive feedback from my classmates motivates my learning process & & & & & \\
\hline Discussion with my classmates facilitated understanding of the topic & & & & & \\
\hline $\begin{array}{l}\text { I would have achieved the same understanding on the subject that I have now with } \\
\text { individual work (inverse) }\end{array}$ & & & & & \\
\hline $\begin{array}{l}\text { My contribution to the well-being of my team was relevant to the development of the } \\
\text { course }\end{array}$ & & & & & \\
\hline
\end{tabular}

Regarding materials, the pedagogical strategy is composed of didactic units. The didactic units of intervention 1 were:

a) Synchronous test for the discussion of mathematical concepts in real contexts. The Socrative tool (https://socrative.com/) was used. Medium and high complexity questions were presented to open the exercise. Initially, questions were answered individually, then collectively. The procedure proposed by [60] was considered. The main elements of GBL considered were: time, the definition of rules, the combination of competitiveness and collaboration, visible status and immediate feedback [8]

b) A crossword puzzle designed for the review of concepts in the subject of limits and derivatives. A proposal with 20 concepts and definitions was prepared with a proposed time of 45 minutes. At the end, the peer evaluation was carried out to verify results. The definition of goals and objectives, rules, immediate feedback, observation of progress and time were considered as the elements of the game (GBL). Furthermore

c) Synchronous test for final exam preparation using the Kahoot platform (https://kahoot.com/schools-u/). A questionnaire was created with 25 questions on all the subjects of the differential calculus course. The time was 120 minutes. Feedback was made at the end of each question. The elements: time, immediate feedback, visible status, competition and visible status were established as the most important. 
Intervention 2 used the Classcraft game (https://www.classcraft.com/en/overview/) as the general platform. In the game, behaviors to stimulate, attitudes to penalize and rules of the game were configured. The students parameterized an avatar with different attributes and characteristics. Working groups were formed with three members called leagues. Two game scenarios were organized, called "maps". The first map included the following activities: 2.A Introduction to the game, 2.B Activity to validate previous knowledge about functions and limits, using Socrative; 2.C Collective debate about the concept of limit of functions in Classcraft; 2.D Collaborative workshop performing simulations of functions and limits in Wolfram Mathematica and 2.E Individual knowledge test using Kahoot. The second map had the following activities: 2.F Workshop on the approximation of the concept of the area from the limit to infinity (https://www.wolfram.com/); 2.G Control of participation in mathematics congress; 2.H Crossword online with review of all the concepts of the course and 2.I Preparation for final exam with the Kahoot tool.

The game's narrative focused on an adaptation of fantastic worlds of superheroes. One activity was performed per week. Status was always visible. All the game elements were used [8].

\section{Results}

After analyzing the data from the scales used (SIMMS and the collaborative learning scale), the results are presented below according to the defined research questions.

\subsection{Research question 1}

Table 2 presents the results of the SIMMS. Intervention 1 and intervention 2 are presented. Items $4,12,7$ and 17 are written in inverse form. The selection criteria to indicate that an item contributes to the category is that the mode is at levels 4 (Mostly true) and 5 (Very true), similar to that proposed by [56], [61].

Intervention 1: Regarding attention, it is confirmed that all items $(1,4,6,12$ and 13) contribute positively to motivation. Relevance presents its four items $(5,8,9$ and 17) at the highest level of the scale. The contribution of the didactic strategy to the motivation is evident. In the confidence category, items 7, 14 and 15 present a high contribution. Item 2, associated with the initial confidence of the student, is presented at level 3 (Moderately true), which motivates to improve the initial presentation of the activities. Item 15 associated with the usefulness of the strategy for the performance in the course is the highest of all the SIMMS results. In general, the confidence category also contributes to motivation in an important way. Finally, in satisfaction, the four items $(3,10,11$ and 16) are at the highest levels of the scale, contributing positively to student motivation.

Intervention 2: Attention has all its items in the upper levels, indicating a positive contribution. Relevance presents the four items at higher levels, highlighting that item 9 (associated with the usability of the activity content) is the highest on the entire scale. The confidence category presents 3 items at level 4 (2, 14 and 15) and one item 
at level 3 (7), which is associated with the difficulty of the exercises. This is the category with the most average of all; however, it is still significant. Finally, satisfaction presents the four items at high levels, ranking positively in motivation. Simulations are highly interesting for the teaching of mathematics because they minimize its abstract nature. Compared to intervention 1, in many cases, lower indicators are presented on the Likert scale. These results can be associated with a "novelty effect", where a small number of innovative educational actions can generate spikes in motivation. However, intervention 2 that takes place over a longer intervention period achieves a point of stability.

Table 2. SIMMS Results

\begin{tabular}{|c|c|c|c|c|c|c|c|c|c|c|}
\hline IMMS & \multicolumn{5}{|c|}{ Intervention 1 (\%) } & \multicolumn{5}{|c|}{ Intervention 2 (\%) } \\
\hline Attention & 1 & 2 & 3 & 4 & 5 & 1 & 2 & 3 & 4 & 5 \\
\hline $\begin{array}{l}\text { 1. There was something } \\
\text { interesting at the begin- } \\
\text { ning of the activities that } \\
\text { got my attention. }\end{array}$ & 0,0 & 0,0 & 19,2 & 30,8 & 50,0 & 0,0 & 0,0 & 9,8 & 66,7 & 23,5 \\
\hline $\begin{array}{l}\text { 4. The exercises that } \\
\text { were presented during } \\
\text { the activities were not } \\
\text { attractive (inverse). } \\
\end{array}$ & 50,0 & 19,2 & 19,2 & 11,6 & 0,0 & 15,1 & 54,4 & 11,9 & 11,9 & 6,7 \\
\hline $\begin{array}{l}\text { 6. The quality of the } \\
\text { activities helped to hold } \\
\text { my attention. }\end{array}$ & 0,0 & 3,8 & 11,6 & 30,8 & 53,8 & 0,0 & 10,1 & 30,5 & 33,7 & 25,7 \\
\hline $\begin{array}{l}\text { 12. These exercises } \\
\text { (activities) were so } \\
\text { abstract that it was hard } \\
\text { to keep my attention on } \\
\text { them (inverse). }\end{array}$ & 38,5 & 15,4 & 23,1 & 19,2 & 3,8 & 12,1 & 40,7 & 37,5 & 9,7 & 0,0 \\
\hline $\begin{array}{l}\text { 13. The activities have } \\
\text { things that stimulated my } \\
\text { curiosity. }\end{array}$ & 0,0 & 3,9 & 3,9 & 57,7 & 34,6 & 0,0 & 16,5 & 27,7 & 29,5 & 26,3 \\
\hline Relevance & 1 & 2 & 3 & 4 & 5 & 1 & 2 & 3 & 4 & 5 \\
\hline \begin{tabular}{|l|} 
5. Completing these \\
activities successfully \\
was important to me. \\
\end{tabular} & 0,0 & 0,0 & 3,8 & 38,5 & 57,7 & 0,0 & 7,3 & 23,4 & 40,5 & 28,8 \\
\hline $\begin{array}{l}\text { 8. Activities are relevant } \\
\text { to my interests. }\end{array}$ & 3,8 & 0,0 & 15,4 & 27,0 & 53,8 & 0,0 & 3,9 & 33,5 & 34,5 & 28,1 \\
\hline $\begin{array}{l}\text { 9. The content of these } \\
\text { activities will be useful } \\
\text { to me. } \\
\end{array}$ & 0,0 & 0,0 & 7,7 & 34,6 & 57,7 & 0,0 & 2,0 & 10,0 & 40,9 & 47,1 \\
\hline $\begin{array}{l}\text { 17. These activities were } \\
\text { not relevant to my needs } \\
\text { because I already knew } \\
\text { most of them (inverse). }\end{array}$ & 34,6 & 30,8 & 11,6 & 19,2 & 3,8 & 20,8 & 38,0 & 36,9 & 4,3 & 0,0 \\
\hline Confidence & 1 & 2 & 3 & 4 & 5 & 1 & 2 & 3 & 4 & 5 \\
\hline $\begin{array}{l}\text { 2. When I first looked at } \\
\text { the activities, I had the } \\
\text { impression that it would } \\
\text { be easy for me. }\end{array}$ & 0,0 & 0,0 & 57,7 & 23,1 & 19,2 & 0,0 & 7,9 & 29,7 & 43,9 & 18,5 \\
\hline
\end{tabular}




\begin{tabular}{|c|c|c|c|c|c|c|c|c|c|c|}
\hline $\begin{array}{l}\text { 7. These exercises were } \\
\text { more difficult to under- } \\
\text { stand than I would like } \\
\text { for them to be (inverse). }\end{array}$ & 7,7 & 34,6 & 30,8 & 19,2 & 7,7 & 7,2 & 28,2 & 55,4 & 9,2 & 0,0 \\
\hline $\begin{array}{l}\text { 14. After working on the } \\
\text { activities for a while, I } \\
\text { was confident that I } \\
\text { would be able to pass a } \\
\text { test on them. }\end{array}$ & 0,0 & 3,8 & 34,6 & 38,5 & 23,1 & 0,0 & 12,0 & 37,4 & 37,5 & 13,1 \\
\hline $\begin{array}{l}\text { 15. The development of } \\
\text { the activities will be } \\
\text { useful to improve my } \\
\text { performance in the } \\
\text { course. }\end{array}$ & 0,0 & 0,0 & 3,8 & 34,6 & 61,5 & 0,0 & 10,5 & 18,8 & 45,4 & 25,3 \\
\hline Satisfaction & 1 & 2 & 3 & 4 & 5 & 1 & 2 & 3 & 4 & 5 \\
\hline $\begin{array}{l}\text { 3. Completing the exer- } \\
\text { cises in the activities } \\
\text { gave me a satisfying } \\
\text { feeling of accomplish- } \\
\text { ment. }\end{array}$ & 0,0 & 3,8 & 11,6 & 46,1 & 38,5 & 2,0 & 15,4 & 24,2 & 31,1 & 27,3 \\
\hline $\begin{array}{l}\text { 10. I really enjoyed } \\
\text { studying these activities. }\end{array}$ & 0 & 3,8 & 7,7 & 42,4 & 46,1 & 0,0 & 5,2 & 31,7 & 36,1 & 27,0 \\
\hline $\begin{array}{l}\text { 11. The positive com- } \\
\text { ments from my teachers } \\
\text { and classmates after } \\
\text { completing the exercises, } \\
\text { made me feel rewarded } \\
\text { for my effort. }\end{array}$ & 0 & 3,8 & 19,2 & 38,5 & 38,5 & 0,0 & 0,0 & 19,2 & 47,9 & 32,9 \\
\hline $\begin{array}{l}\text { 16. It felt good to suc- } \\
\text { cessfully complete these } \\
\text { activities. }\end{array}$ & 0 & 0 & 3,8 & 46,1 & 50,1 & 0,0 & 6,7 & 22,2 & 37,1 & 34,0 \\
\hline
\end{tabular}

The shaded cells represent the mode statistic for each question.

Comparing the results between each category of the ARCS model as mentioned in the methodology, we find (descending order): Intervention 1 was: Satisfaction (40), Relevance (39.5), Attention (36.5) and Confidence (30, 2). The result of intervention 2 was: Relevance (33.6), Satisfaction (33), Attention (30.6) and Confidence (27). In both interventions, it is observed that the Satisfaction / Relevance categories present the highest values. Confidence is the category with the lowest weighting on the part of the students and should be prioritized for future designs.

\subsection{Research question 2}

Table 3 presents the analysis of correlation of collaboration and motivation (related in the four categories of the ARCS model). For intervention 1, the relationship was not found to be statistically significant. In intervention 2, a statistically significant and directly proportional linear relationship was found between: collaboration - care $(\mathrm{Rp}=$ 0.391 , Sig $<0.05)$, collaboration-trust $(\mathrm{Rp}=0.354$, Sig $<0.05)$, collaboration relevance $(\mathrm{Rp}=0.439, \mathrm{Sig}<0.05)$ and collaboration-satisfaction $((\mathrm{Rp}=0.448, \mathrm{Sig}$ $<0.05)$. 
Table 3. ARCS Correlations between collaboration and categories of the ARCS model

\begin{tabular}{|l|l|l|c|c|c|c|c|}
\hline Variable & Intervention & & $\begin{array}{c}\text { Collabo- } \\
\text { ration }\end{array}$ & Attention & Confidence & Relevance & $\begin{array}{c}\text { Satis- } \\
\text { faction }\end{array}$ \\
\hline \multirow{4}{*}{$\begin{array}{l}\text { Collabora- } \\
\text { tion }\end{array}$} & \multirow{3}{*}{1} & Pearson Correlation & 1 & .024 & -.165 & .169 & .086 \\
\cline { 2 - 8 } & & Sig. (2-tailed) & & .909 & .420 & .410 & .675 \\
\cline { 2 - 8 } & \multirow{2}{*}{2} & Pearson Correlation & 1 & $.391^{* *}$ & $.354^{* *}$ & $.439^{* *}$ & $.448^{* *}$ \\
\cline { 2 - 8 } & & Sig. (2-tailed) & & .003 & .008 & .001 & .001 \\
\cline { 2 - 8 } & $\mathrm{N}$ & 55 & 55 & 55 & 55 & 55 \\
\hline
\end{tabular}

**. The correlation is significant at the 0.01 level (bilateral).

*. The correlation is significant at the 0.05 level (bilateral).

\subsection{Research question 3}

Figure 1 shows the dropout levels of the differential calculus course in the last 8 periods. The dropout level decreases moderately in the periods of interventions 0,1 and 2. It is highlighted that the last period (2019-II) has a single digit dropout (7\%).

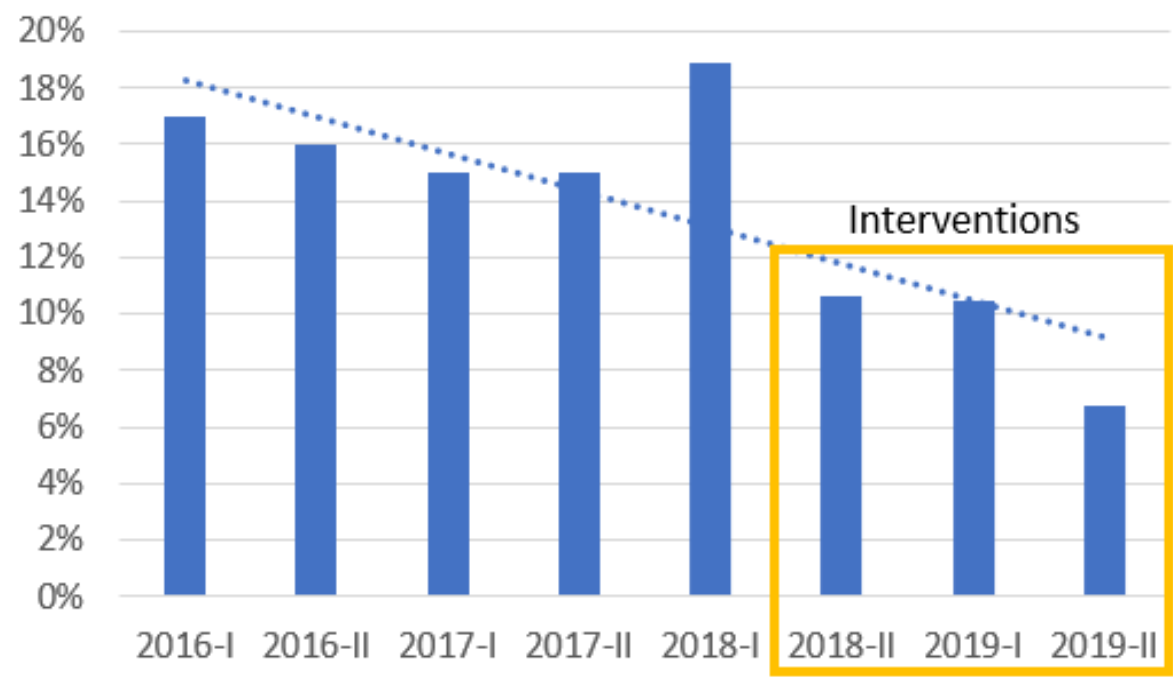

Fig. 1. Dropout levels trend in the differential calculus course

This result is still preliminary to generate long-term conclusions, however a trend is observed that may decrease early dropout [32] and the influence of the lack of contextualization [34].

\section{Discussion}

The results agree with [19] regarding the contribution of the pedagogical strategy in the different aspects of the ARCS model [35]. Digital games are very common in 
the target population and this is positively related to their interest in using them in class. The technological tool, unlike what was proposed in [62], does not become a distraction but rather an ally of the strategy. The proposal explores cognitive, motivational and affective aspects; that are fundamental in the incorporation of games in education [23]. The results coincide with that indicated by [15] in terms of increasing the attention and focus of the students, as well as facilitating their learning.

The results show that the categories Attention, Relevance, Confidence and Satisfaction are at high levels. This allows us to infer that motivation, associated with these factors, increases with the use of GBL and gamification. This coincides with that shown in [3], [63]. It is also observed that the characteristics of the teaching units, such as the quality of the materials, the immediate and pertinent feedback from the teacher, the relationship of the activities with the context and the interests of the student, group work and the way to present the activity, are very relevant. This aspect, associated with the design, is consistent with what was cited by [55].

Since various activities are oriented to problem solving, it is possible to indicate that there is evidence that the GBL-mediated teaching strategy can also help to generate the scaffolding necessary for solving mathematical problems. In turn, it is important to consider the possible frustration of some students, which may negatively affect the process. This coincides with what is proposed by [64]. The scaffolding results are also consistent with that presented by [18], who indicate that the results show that both hard scaffold and soft scaffold have positive impacts on motivation and academic performance.

There are also negative aspects of the use of game elements in educational processes that must be considered. Some professors who participated in the research indicated that students constantly request an increase in the quantitative assessment if they are actively involved in the initiative. This can promote an increase in extrinsic motivation, affecting the intrinsic motivation of the being, in coherence with what was exposed by [65], [66]. This should be reviewed in more detail in future work.

Regarding intervention 1, it is possible to affirm that the result can be associated with the fact that only one of the three activities proposed has explicit teamwork. Furthermore, in the development of the activity, in several cases, the result of teamwork was less effective than the individual result. Intervention 2 generated more spaces for teamwork, promoting collaborative learning. Collaboration becomes a relevant strategy in the incorporation of games in educational environments, coinciding with [67] in the motivation to network. It also allows enhancing the meaning that the student finds in his/her training process [60]. The cohesion generated by the concept of league (working group) also generated positive effects on motivation (intervention 2) that were not observed in intervention 1.

\section{Conclusion}

The present study is aimed to investigate the effect of gamification and game-based learning on students' motivation and dropout from first-year engineering math courses. The findings initiate that the students who use game-based pedagogical strategies 
have high levels of motivation, registered in the dimensions of Attention, Relevance, Confidence and Satisfaction. There is a more significant result in motivation in intervention 1 than in intervention 2; however, this can be associated with the novel effect that formative actions with games produce in short periods of time. Intervention 2 was carried out over a much longer period and with more activities, which achieved a point of stability.

An important aspect is planning processes and defining clear rules for students (players). The quality of the materials and the feedback from the teacher as well. Activities with a striking narrative and related to the interests of the students are also important for the design of the pedagogical strategy. It is also found that collaboration fosters student motivation, generating appropriate collaborative learning scenarios. The cohesion produced by group activities (concept of leagues) fosters student motivation. The increase in the characteristics of the avatar and the league motivates students to carry out their training activities with higher quality. There is initial empirical evidence to project that dropping out of the course has a decreasing trend line when educational games are implemented.

In conclusion, gamification and game-based learning (GBL) can be used to strengthen educational processes in engineering with very promising results in terms of motivation. Extending this research to other areas such as physics and applied engineering may be relevant.

\section{Acknowledgement}

The authors of this study thank the financial support of the Universidad Santo Tomas-Colombia and the academic support of the University of the Balearic IslandsSpain. The contributions of the Engineer Dayan Ardila-Segovia are also appreciated.

\section{$7 \quad$ References}

[1] S. Deterding, D. Dixon, R. Khaled, and L. Nacke, "From Game Design Elements to Gamefulness: Defining 'Gamification,"' in Proceedings of the 15th International Academic MindTrek Conference: Envisioning Future Media Environments, 2011, pp. 915. https://doi.org/10.1145/2181037.2181040

[2] G. Barata, S. Gama, J. Jorge, and D. Gonçalves, "Studying student differentiation in gamified education: A long-term study," Comput. Human Behav., vol. 71, pp. 550-585, 2017. https://doi.org/10.1016/j.chb.2016.08.049

[3] Z. Zainuddin, S. K. W. Chu, M. Shujahat, and C. J. Perera, "The impact of gamification on learning and instruction: A systematic review of empirical evidence," Educ. Res. Rev., vol. 30, no. February, 2020. https://doi.org/10.1016/j.edurev.2020.100326

[4] A. M. Toda, R. M. C. do Carmo, A. P. da Silva, I. I. Bittencourt, and S. Isotani, "An approach for planning and deploying gamification concepts with social networks within educational contexts," Int. J. Inf. Manage., vol. 46, no. October 2018, pp. 294-303, 2019. https://doi.org/10.1016/j.ijinfomgt.2018.10.001 
[5] L. Bennis and S. Amali, "From Learning Game to Adaptive Ubiquitous Game Based Learning," Int. J. Emerg. Technol. Learn., vol. 14, no. 16, pp. 55-65, 2019. https://doi. org/10.3991/ijet.v14i16.10701

[6] M. Qian and K. R. Clark, "Game-based Learning and 21st century skills: A review of recent research," Comput. Human Behav., vol. 63, pp. 50-58, 2016. https://doi.org/10. 1016/j.chb.2016.05.023

[7] D. W. Shaffer, K. R. Squire, R. Halverson, and J. P. Gee, "Video Games and the Future of Learning," Phi Delta Kappan, vol. 87, no. 2, pp. 105-111, Oct. 2005. https://doi.org/ $\underline{10.1177 / 003172170508700205}$

[8] Observatorio de Innovación Educativa del Tecnológico de Monterrey, "EdutrensGamificacion," Monterrey - México, 2018.

[9] L. De-Marcos, E. Garcia-Lopez, and A. Garcia-Cabot, "On the effectiveness of game-like and social approaches in learning: Comparing educational gaming, gamification \& social networking," Comput. Educ., vol. 95, pp. 99-113, 2016. https://doi.org/10.1016/j. compedu.2015.12.008

[10] T. Hainey, T. M. Connolly, E. A. Boyle, A. Wilson, and A. Razak, "A systematic literature review of games-based learning empirical evidence in primary education," Comput. Educ., vol. 102, pp. 202-223, 2016. https://doi.org/10.1016/j.compedu.2016.09.001

[11] T. M. Connolly, E. A. Boyle, E. MacArthur, T. Hainey, and J. M. Boyle, "A systematic literature review of empirical evidence on computer games and serious games," Comput. Educ., vol. 59, no. 2, pp. 661-686, 2012. https://doi.org/10.1016/j.compedu.2012.03.004

[12] L. Fonseca-Tovar, C. Suarez-Gasca, and S. Zabala-Vargas, "Estrategias pedagógicas, fundamentadas en Aprendizaje Basado en Juegos, para el mejoramiento en el proceso de enseñanza del concepto de fracciones matemáticas, en estudiantes de último nivel de básica primaria," in Las competencias y la sociedad del conocimiento, 1st ed., CIMTED, Ed. Medellín, 2018, pp. 130-154. https://doi.org/10.15665/esc.v13i2.601

[13] S. A. Zabala-Vargas, D. A. Ardila-Segovia, L. H. García-Mora, and B. L. d. BenitoCrosetti, "Game-based learning (GBL) applied to the teaching of mathematics in higher education. A systematic review of the literature," Form. Univ., vol. 13, no. 1, pp. 13-26, 2020. https://doi.org/10.4067/s0718-50062020000100013

[14] S. Zabala-Vargas, L. García-Mora, and B. de Benito, "Estrategia pedagógica con aprendizaje basado en juegos-GBL, para fomentar la motivación en el área de matemáticas en ingeniería.," in CIEBC2019, 2019, p. 16. https://doi.org/10.4067/s0718-50062020000 100013

[15] T. Partovi and M. R. Razavi, "The effect of game-based learning on academic achievement motivation of elementary school students," Learn. Motiv., vol. 68, no. August, p. 101592, 2019. https://doi.org/10.1016/j.lmot.2019.101592

[16] J. Andrew, S. Henry, A. N. Yudhisthira, Y. Arifin, and S. D. Permai, "Analyzing the factors that influence learning experience through game based learning using visual novel game for learning pancasila," Procedia Comput. Sci., vol. 157, pp. 353-359, 2019. https://doi.org/10.1016/j.procs.2019.08.177

[17] J. Hamari, D. J. Shernoff, E. Rowe, B. Coller, J. Asbell-Clarke, and T. Edwards, "Challenging games help students learn: An empirical study on engagement, flow and immersion in game-based learning," Comput. Human Behav., vol. 54, pp. 170-179, 2016. https://doi.org/10.1016/j.chb.2015.07.045

[18] C. H. Chen and V. Law, "Scaffolding individual and collaborative game-based learning in learning performance and intrinsic motivation," Comput. Human Behav., vol. 55, pp. 1201-1212, 2016. https://doi.org/10.1016/j.chb.2015.03.010 
[19] A. Galbis Córdova, J. Martí Parreño, and R. Currás Pérez, "Higher education students' attitude towards the use of gamification for competencies development," 2017. https://doi.org/10.1080/14703297.2019.1683464

[20] R. Hämäläinen, T. Manninen, S. Järvelä, and P. Häkkinen, "Learning to collaborate: Designing collaboration in a 3-D game environment," Internet High. Educ., vol. 9, no. 1, pp. 47-61, 2006. https://doi.org/10.1016/j.iheduc.2005.12.004

[21] F. Ke and Y.-C. Hsu, "Mobile augmented-reality artifact creation as a component of mobile computer-supported collaborative learning," Internet High. Educ., vol. 26, pp. 3341, 2015. https://doi.org/10.1016/j.iheduc.2015.04.003

[22] K. Kiili, "Digital game-based learning: Towards an experiential gaming model," Internet High. Educ., vol. 8, no. 1, pp. 13-24, 2005. https://doi.org/10.1016/j.iheduc.2004.12.001

[23] J. L. Plass, B. D. Homer, and C. K. Kinzer, "Foundations of Game-Based Learning," Educ. Psychol., vol. 50, no. 4, pp. 258-283, 2015. https://doi.org/10.1080/00461520.2015. $\underline{1122533}$

[24] H. Bicen and S. Kocakoyun, "Perceptions of students for gamification approach: Kahoot as a case study," Int. J. Emerg. Technol. Learn., vol. 13, no. 02, pp. 72-93, 2018. https://doi.org/10.3991/ijet.v13i02.7467

[25] W. M. A. F. W. Hamzah, N. H. Ali, M. Y. M. Saman, M. H. Yusoff, and A. Yacob, "Influence of gamification on students' motivation in using E-learning applications based on the motivational design model," Int. J. Emerg. Technol. Learn., vol. 10, no. 2, pp. 3034, 2015. https://doi.org/10.3991/ijet.v10i2.4355

[26] M. D. Hanus and J. Fox, "Assessing the effects of gamification in the classroom: A longitudinal study on intrinsic motivation, social comparison, satisfaction, effort, and academic performance," Comput. Educ., vol. 80, pp. 152-161, 2015. https://doi.org/10. 1016/j.compedu.2014.08.019

[27] E. Zimmerling, C. E. Höllig, P. G. Sandner, and I. M. Welpe, "Exploring the influence of common game elements on ideation output and motivation," J. Bus. Res., vol. 94, no. February, pp. 302-312, 2019. https://doi.org/10.1016/j.jbusres.2018.02.030

[28] ABET, "Criteria For Accrediting Engineering Programs," Engineering Accreditation Commission, Baltimore, 2016.

[29] M. Dunn, B. Loch, and W. Scott, "The effectiveness of resources created by students as partners in explaining the relevance of mathematics in engineering education," Int. $J$. Math. Educ. Sci. Technol., vol. 49, no. 1, pp. 31-45, 2018. https://doi.org/10.1080/0020 739x.2017.1338771

[30] ENAEE, “EUR-ACE® Framework Standards and Guidelines,” 2015.

[31] Ministerio de Educación Nacional de Colombia, "Estadísticas del Sistema para la Prevención y Análisis de la Deserción en las Instituciones de Educación Superior SPADIES," 2019. [Online]. Available: https://www.mineducacion.gov.co/sistemasde informacion/1735/w3-article-357549.html? noredirect=1. recimundo/2.(3).julio.2018.666-679

[32] E. Castaño, S. Gallón, K. Gómez, and J. Vásquez, "Análisis de los factores asociados a la deserción y graduación estudiantil universitaria.\&nbsp;," Lect. Econ., no. 65, pp. 9-36, 2006.

[33] Ministerio de Educación Nacional, "Deserción estudiantil en la educación superior colombiana-\&nbsp;Metodología de seguimiento, diagnóstico y elementos para su prevención," 2009. https://doi.org/10.31619/caledu.n17.409

[34] V. Tinto, "Definir la deserción: una cuestión de perspectiva," Rev. Educ. Super., vol. 18, no. 3, pp. 33-51, 1989. 
[35] J. M. Keller, Motivational Design for Learning and Performance- The ARCS Model Approach, vol. 1, no. 1. Tallahasse: Springer, 2010.

[36] H. Astleitner and M. Hufnagl, "The effects of situation-outcome-expectancies and of ARCS-strategies on self-regulated learning with web-lectures," J. Educ. Multimed. hypermedia, vol. 12, no. 4, pp. 361-376, 2003.

[37] J. D. House, "Instructional activities and interest in science learning for adolescent students in Japan and the United States: Findings from the Third International Mathematics and Science Study (TIMSS)," Int. J. Instr. Media, vol. 30, no. 4, pp. 429-443, 2003.

[38] K. Li and J. M. Keller, "Use of the ARCS model in education: A literature review," Comput. Educ., vol. 122, no. March, pp. 54-62, 2018.

[39] S. Annamalai, "Implementing ARCS model to design a motivating multimedia e-book for polytechnic ESL classroom," J. Telecommun. Electron. Comput. Eng., vol. 8, no. 8, pp. 57-60, 2016.

[40] W. Huang, W. Huang, H. Diefes Dux, and P. K. Imbrie, "A preliminary validation of Attention, Relevance, Confidence and Satisfaction model based Instructional Material Motivational Survey in a computer based tutorial setting," Br. J. Educ. Technol., vol. 37, no. 2, pp. 243-259, 2006. https://doi.org/10.1111/j.1467-8535.2005.00582.x

[41] H. Karakıs, A. Karamete, and A. Okçu, "The effects of a computer-assisted teaching material, designed according to the assure instructional design and the ARCS model of motivation, on students' achievement levels in a mathematics lesson and their resulting attitudes," Eur. J. Contemp. Educ., vol. 15, no. 1, pp. 105-113, 2016. https://doi.org/ $\underline{10.13187 / \text { ejced.2016.15.105 }}$

[42] P.-L. Wu, C.-H. Tsai, T.-H. Yang, S.-H. Huang, and C.-H. Lin, "Using ARCS Model to Promote Technical and Vocational College Students' Motivation and Achievement.," Int. J. Learn., vol. 18, no. 4, 2012.

[43] C. H. Cheng and C. H. Su, "A Game-based learning system for improving student's learning effectiveness in system analysis course," Procedia - Soc. Behav. Sci., vol. 31, no. 2011, pp. 669-675, 2012. https://doi.org/10.1016/j.sbspro.2011.12.122

[44] J. V Dempsey and R. Burke Johnson, "The development of an ARCS gaming scale," $J$. Instr. Psychol., vol. 25, no. 4, pp. 215-221, 1998.

[45] M. Hamizul and N. M. Rahimi, "Design and Development of Arabic Online Games - A Conceptual Paper,” Procedia - Soc. Behav. Sci., vol. 174, pp. 1428-1433, 2015. https://doi. org/10.1016/j.sbspro.2015.01.771

[46] K.-C. Hao and L.-C. Lee, "The development and evaluation of an educational game integrating augmented reality, ARCS model, and types of games for English experiment learning: an analysis of learning," Interact. Learn. Environ., pp. 1-14, 2019. https://doi.org/10.1080/10494820.2019.1619590

[47] J. D. Klein, "Effect of instructional gaming and reentry status on performance and motivation," Contemp. Educ. Psychol., vol. 17, no. 4, pp. 364-370, 1992. https://doi.org/ $\underline{10.1016 / 0361-476 x(92) 90074-9}$

[48] T. Wu, "Improving the effectiveness of English vocabulary review by integrating ARCS with mobile game based learning," J. Comput. Assist. Learn., vol. 34, no. 3, pp. 315-323, 2018. https://doi.org/10.1111/jcal.12244

[49] C.-M. Chen, M.-C. Li, and T.-C. Chen, "A web-based collaborative reading annotation system with gamification mechanisms to improve reading performance," Comput. Educ., vol. 144, p. 103697, 2020. https://doi.org/10.1016/j.compedu.2019.103697

[50] C.-W. Liao, C.-H. Chen, and S.-J. Shih, "The interactivity of video and collaboration for learning achievement, intrinsic motivation, cognitive load, and behavior patterns in a 
digital game-based learning environment," Comput. Educ., vol. 133, pp. 43-55, 2019. https://doi.org/10.1016/j.compedu.2019.01.013

[51] M. J. Sousa and Á. Rocha, "Leadership styles and skills developed through game-based learning," J. Bus. Res., vol. 94, pp. 360-366, 2019. https://doi.org/10.1016/j.jbusres.2018. $\underline{01.057}$

[52] C. Troussas, A. Krouska, and C. Sgouropoulou, "Collaboration and fuzzy-modeled personalization for mobile game-based learning in higher education," Comput. Educ., vol. 144, p. 103698, 2020. https://doi.org/10.1016/j.compedu.2019.103698

[53] B. De Benito Crosetti and J. M. Salinas Ibáñez, "La Investigación Basada en Diseño en Tecnología Educativa," Rev. Interuniv. Investig. en Tecnol. Educ., no. 0, pp. 44-59, 2016. https://doi.org/10.6018/riite2016/260631

[54] S. McKenney and T. C. Reeves, Conducting educational design research. Routledge, 2018.

[55] C. Castaño Garrido, I. Maiz Olazabalaga, and U. Garay Ruiz, "Diseño, motivación y rendimiento en un curso MOOC cooperativo," Comun. Rev. cientifica Iberoam. Comun. $y$ Educ., no. 44, pp. 19-26, 2015. https://doi.org/10.3916/c44-2015-02

[56] Á. Di Serio, M. B. Ibáñez, and C. D. Kloos, "Impact of an augmented reality system on students' motivation for a visual art course," Comput. Educ., vol. 68, pp. 586-596, 2013. https://doi.org/10.1016/j.compedu.2012.03.002

[57] M. B. Ibáñez, A. Uriarte Portillo, R. Zatarain Cabada, and M. L. Barrón, "Impact of augmented reality technology on academic achievement and motivation of students from public and private Mexican schools. A case study in a middle-school geometry course," Comput. Educ., vol. 145, no. October 2019, 2020. https://doi.org/10.1016/j.compedu.2019. 103734

[58] Y. K. Turel and S. Ozer Sanal, "The effects of an ARCS based e-book on student's achievement, motivation and anxiety," Comput. Educ., vol. 127, no. August, pp. 130-140, 2018. https://doi.org/10.1016/j.compedu.2018.08.006

[59] N. Loorbach, O. Peters, J. Karreman, and M. Steehouder, "Validation of the Instructional Materials Motivation Survey (IMMS) in a self-directed instructional setting aimed at working with technology," Br. J. Educ. Technol., vol. 46, no. 1, pp. 204-218, Jan. 2015. https://doi.org/10.1111/bjet.12138

[60] E. Mazur, Peer Instruction: A User's Manual. Prentice Hall, 1997.

[61] C. Castaño, I. Maiz, and U. Garay, "Design, Motivation and Performance in a Cooperative MOOC Course," Comunicar, vol. 44, pp. 19-26, 2015. https://doi.org/10.3916/c44-2015$\underline{02}$

[62] M. Kebritchi, A. Hirumi, and H. Bai, "The effects of modern mathematics computer games on mathematics achievement and class motivation," Comput. Educ., vol. 55, no. 2, pp. 427-443, 2010. https://doi.org/10.1016/j.compedu.2010.02.007

[63] G. Barata, S. Gama, M. J. Fonseca, and D. Gonçalves, "Improving student creativity with gamification and virtual worlds," in Proceedings of the First International Conference on Gameful Design, Research, and Applications, 2013, pp. 95-98. https://doi.org/10.1145/ $\underline{2583008.2583023}$

[64] Y. Chen, "Empirical study on the effect of digital game-based instruction on students' learning motivation and achievement," Eurasia J. Math. Sci. Technol. Educ., vol. 13, no. 7, pp. 3177-3187, 2017. https://doi.org/10.12973/eurasia.2017.00711a

[65] R. Derfler-Rozin and M. Pitesa, "Motivation Purity Bias: Expression of Extrinsic Motivation Undermines Perceived Intrinsic Motivation and Engenders Bias in Selection Decisions," Acad. Manag. J., no. ja, 2020. https://doi.org/10.5465/amj.2017.0617 
[66] L. Facey-Shaw, M. Specht, P. Van Rosmalen, and J. Bartley-Bryan, "Do Badges Affect Intrinsic Motivation in Introductory Programming Students?," Simul. Gaming, p. 1046878119884996, 2020. https://doi.org/10.1177/1046878119884996

[67] C. Suárez-Guerrero and B. Gros-Salvat, Aprender en red. De la interacción a la colaboración, Primera ed., vol. 52. Barcelona: Universitat Oberta de Catalunya, 2013.

\section{Authors}

Sergio Zabala-Vargas has an Electronic Engineering degree. He has a Master's degree in project management and a second Master's degree in e-learning. He has been a professor in the Telecommunications Engineering program at the Universidad Santo Tomás-Colombia. He is studying the last year of a Doctorate in educational technology from the University of the Balearic Islands. He is recognized as a Senior Researcher by the Ministry of Science, Technology and Innovation-MINCIENCIAS.

Lewis García-Mora is a Psychologist, Specialist in family intervention, Master in education and human development. University professor in topics such as: educational research, quality in education in Colombia and didactics. Currently curricular advisor and leader of the ESPIRAL educational and pedagogical research group of the Santo Tomás University -Bucaramanga.

Edgar Arciniegas Hernández has a Master's degree in education and has specialised in University teaching. Graduate in Mathematics. He has been a professor in the Engineering and Economic Science Divisions at the Universidad Santo TomásColombia for over 11 years and academic coordinator of the Economic Science Division in the areas of Mathematics and Statistics. He currently participates as coresearcher in projects of the GICIBAYA research group.

Jerson Reina-Medrano is a full-time professor of mathematics and physics at the Universidad Santo Tomás. The author obtained his PhD degree in Physics at Universidad Industrial de Santander. His main research areas are astrophysics and galactic dynamics. Currently, he is interested in topics related to education sciences.

Barbara de Benito Crosetti is a professor of Educational Technology at the University of Balearic Islands. She has National and International experience in teaching degree and post-graduate courses and teacher training. Member of the Education Technology Group, since its creation in 1992. Founder member and advisor to the spin-off Zairja. Soluciones en Formación y Gestión del Conocimiento S.L.

Antonia Darder-Mésquida is a professor of Educational Technology at the University of Balearic Islands and research member of the Educational Technology Group. She has experience in teaching degree and post-graduate courses and teacher training.

Article submitted 2020-06-08. Resubmitted 2020-07-15. Final acceptance 2020-07-17. Final version published as submitted by the authors. 